\title{
The Development of Learning Media by Using Cooperative Learning Model
}

\author{
Abdon Purwanto Purba \\ Educational Technology, Postgraduate Program \\ Universitas Negeri Medan \\ Medan, Indonesia \\ Corresponding email: abdonpurwanto@yahoo.co.id
}

\author{
Muhammad Badiran \\ Educational Technology, Postgraduate Program \\ Universitas Negeri Medan \\ Medan, Indonesia
}

\author{
Farihah \\ Educational Technology, Postgraduate Program \\ Universitas Negeri Medan \\ Medan, Indonesia
}

\begin{abstract}
This study aims to : (1) know the feasibility of developed learning media, (2) determine the effectiveness of learning media in improving student music learning outcomes.

The design of learning media is using the development method of Research and Development (R\&D) with Dick \& Carey Model combined with Cooperative learning Model. Development of this learning media using Macromedia flash application program. The research subject was students in grade 5 students of elementary school in Husni Thamrin Medan in 2017/2018 academic year.
\end{abstract}

Keywords-learning media, music, cooperative learning .

\section{INTRODUCTION}

The education of music art is not just entertainment to provoke students into the spirit of learning, as some of the teachers have echoed. The education of music art that the art of music is a work of art in the form of sounds of songs or compositions that expressing the thoughts and feelings of the creator through the main elements of music that is the rhythm, melody, harmony, and the form or structure of song and expression as a unity [1] . The education of music art has learning component in its learning process those are (1) expression, (2) appreciation, and (3) creation of music art, either in theory or practice [2].

The education of music arts includes the concepts and importance of the art of music, elements such as: rhythm, notation, birama, melody, key signs and signs, scales, expression (tempo, dynamics, and color), the form and structure of songs, vocals, musical experiences, the practice of music art learning and the relevance of music art with learning in primary schools, learning problems of music art

Although the importance of the process of learning music art, however there are problems in the learning process. There are some problems gained in the process of learning the art of music is a model of learning applied by teachers and learning media which used by teachers and students.
The development of learning media is important to make the learning process which is done into a fun learning process and provide a good experience for students. One of the media that can be used in the development of learning media is macromedia flash software. Macromedia Flash software can produce files with small size. This is because flash uses an animation with a base vector, and also the size of this small flash file can be used on a web page without requiring long loading time to open it. So from these advantages can make learning media so much easier and easy to be used by learners.

The development of the media can not be removed by the use of learning models that must be applied in the learning process. The learning model is a set of sequential procedures for realizing a process, such as needs assessment, media selection and evaluation. One of the learning models that can be used and combined with instructional media is cooperative learning model.

Cooperative learning learning model is a learning strategy that organizes learning by using small study groups where, students work together to achieve learning goals [6]. In addition, the principle of cooperative learning model is 1) positive interdependence 2) individual responsibility; 3) faceto-face; 4) communication among members; and 5) group process evaluation [7]

The benefits of Cooperative Learning include: improving student learning activities and academic achievement, assisting students in developing communication skills orally, developing students 'social skills, improving students' selfconfidence, helping to improve positive relationships among students [8].

Cooperative learning model has a basis on the theory of cognitive psychology and social learning theories. The focus of cooperative learning is not only focused on what the learners do but also on what the learners think during the learning activities take place. The information contained in the curriculum is not simply transferred by the teacher to the 
learners, but the learners are facilitated and motivated to interact with other learners in the group, with the teacher and with the instructional materials optimally in order to be able to construct his own knowledge. In the cooperative learning model, teachers act as facilitators, providers of learning resources for learners, guiding learners in group learning, motivating learners in solving problems, and coaching learners to have cooperative skills.

Through the development of instructional media by using cooperative learning model, students are expected to make the learning process more easier for students in understanding the subject matter of music art, which is presented by the teacher and expected with the use of media can make the learning process becomes more meaningful for students

\section{METHOD}

This research was conducted at Husni Thamrin school, Medan, North Sumatera, Indonesia. Implementation of this research was adjusted to the educational calendar and for the implementation of product trial conducted in the form of learning activities for 3 meetings, each $2 \times 45$ minutes per meeting. The trial activity of this product was done in computer laboratory. After conducting product trials, then tested the effectiveness of product development results. The trial and test of the effectiveness of this product was conducted at Husni Thamrin school, Medan, North Sumatera, Indonesia.

This research was a study of learning media development using cooperative learning model. This research and development includeed the process of developing and testing the effectiveness of the product. Research and development was a research method used to produce a particular product, and test the effectiveness of the product [9]. The design of the research and development model used in this research was the Borg \& Gall development model [10]. The steps in this study using 2 stages of the first stage was to develop with the media to produce a product and the second stage was to determine the effectiveness of the product. To produce learning media products by using cooperative learning model that was feasible to use and in accordance with the needs, it was necessary to take a research approach. In general, research and development model was a suitable method to develop and test a product.

The steps of the development stage are as follows:

a. Conducting preliminary research which includes:

1) Identify learning needs and determine subject competency standards

2) Conduct learning analysis

3) Identify the characteristics and behavior of students early

4) Write basic competencies and indicators

5) Write benchmark reference tests

6) Develop learning strategies embodied in the form of syllabus and learning unit
7) Develop learning materials

b. Making software design, which includes:

1) Scripting

2) Making storyboards

3) Creation of flowchartview

c. Collection of materials including:

1) Creation and collection of images and animations

2) Recording and audio collection

d. Development of learning materials, divided into 2 types, namely:

1) Content development

2) Development of interactive media which includes: designing, collecting materials or interactive media materials and making interactive media and its development

e. Reviewing and revision of instructional media

f. Trial of instructional media early product

To produce learning media product by using cooperative learning model which is feasible to use and according to requirement, hence need to be taken a research approach. In general, research and development model is a suitable method to develop and test a product.

\section{RESULT AND DISCUSSIONS}

a. Result

Results from the dispersed questionnaire found that $75 \%$ (percent) of teachers stated that they needed instructional media in the learning process to make the learning process more effective, and $100 \%$ of students stated that they needed individual learning. Based on product validation through a series of tests and revisions that have been done, then the learning media on music art subjects have a valid status. The experiments were conducted in 4 stages: (1) evaluation of material experts, design learning experts, and software engineering experts, (2) individual testing, (3) small group trials, and (4) field trials.

The expert evaluates the learning media by using cooperative learning model on music art subjects based on three aspects, namely the quality of instructional materials and the quality of teaching delivery system which showed the average percentage of the assessment of $96,25 \%$ each on the quality aspect of learning material, 94,00\% on the quality aspects of learning strategies, and $95.00 \%$ on the aspects of the delivery system including the category of excellent overall, which means learning media by using cooperative learning model on the subjects of music art can meet the demands of learning needs.

Assessment of the design expert of learning on the aspect of the quality of information design showed the average percentage of $92.50 \%$ including very good category, which means the learning media information by using cooperative learning model on music art subjects can provide easiness for students to obtain the desired information. The assessment of the design expert on the aspect of the quality of interactive design showes an average percentage of $90.00 \%$ including the 
excellent category which means the learning content arrangement concerns the interaction aspect between the learners with the learning so as to create a condition that is able to facilitate learning.

While the average percentage of the presentation design spec is $98.33 \%$ including the category very well which means the presentation of the developed learning media has an interesting appearance so be able to generate a sense of interest of students to do learning. Based on the assessment of instructional media using cooperative learning model on music art subjects in individual trials there is no suggestion of improvement.

The results of research on learning media using cooperative learning model in students at high school in Husni Thamrin Grade 5: quality aspect was $91,39 \%$ and best quality and appearance was $95,87 \%$ and each use was included in very good category. Thus, measurements made on learning media using cooperative learning models on subjects conducted in various experiments will be very good and needed without any problems that have to be fixed.

The results of the assessment of learning media using cooperative learning model on music art subjects on field trials showed that the product developed very well or feasible to use and no suggestion of improvement submitted in this field trial so that no revision done

Field trials were also conducted at Husni Thamrin Class 5 consisting of 80 students, namely A class of 40 students and class B of 40 students. Field trials produced data that would measure the feasibility of the product being developed, and to know how the product benefits to the wearer. The results of the evaluation of instructional media on the quality aspects of learning materials can be seen in table 1 . The results of field trials research on the quality aspects of learning materials on learning media using cooperative learning model on music art subjects had been summarized in table 3 .

Based on the assessment of learning media by using cooperative learning model on music art subjects in field test with 80 students of Husni Thamrin for the quality aspects of learning materials and technical / display quality aspects showed that the product developed is very good or feasible to use.

The hypothesis proposed in this study was to know the effectiveness of the learning media by using cooperative learning model on music art subjects to the improvement of student learning outcomes in the subject of musical arts the subject of "ansambel music". So then on hypothesis testing can use t test of Pre-test and Post-test t.

\section{1) Pre-Test}

Having the data feasibility test was completed, then t test was done pre-test research. This was done to determine if there was difference of initial ability of control class and experiment class by using $t$ test pre-test.

Based on the calculation that had been done, obtained the output with $t$ count equal to -2.31 and t table equal to 1.67 at $95 \%$ confidence level. Then obtained that $\mathrm{t}$ count $(t$ hitung $)<\mathrm{t}$ table or $-2.31<1.67$ or in other words $\mathrm{Ha}$ rejected. This indicated that the initial ability of control class students and experimental class is likely to be the same and there is no significant difference

\section{2) Post-Test}

Having the pre-test was done, then the hypothesis was tested by using post-test $t$ test. This was done to determine whether there were differences in student learning outcomes after being taught using different media. The hypothesis of this research is as follows:

Ha: Student learning outcomes by using learning media by using cooperative learning learning model on music art subjects

Ho: Student learning outcomes by using conventional learning media

Based on the research that had been done on the results of learning music art on students who were given by using learning media which using cooperative learning model on music art subjects, it is found that the score of student learning outcomes from 40 respondents spread on vulnerable 50-100. The results showed that the lowest score 50 and the highest score 100, mean 72.50 and median 70 and standard deviation 9.45. Based on the calculation, then obtained data that $t$ count ( $t$ hitung) $>$ t table or 4.51>1.67 or in other words Ho rejected and $\mathrm{Ha}$ accepted, it can be concluded that the learning outcomes of students who are given learning by using learning media using cooperative learning model learning on music art subjects is higher than student learning outcomes by using conventional learning media with the effectiveness of the interaction is equal to $73.67 \%$.

\section{b. Discussion}

Learning media development product by using cooperative learning model in music art subject is a learning material that has been developed by paying attention to learning and media aspects as learning instruction design principle. Product development research conducted is directed to produce a product in the form of learning media by using cooperative learning learning model on music art subjects for Husni Thamrin students. Product development research conducted is directed to produce a product in the form of instructional media by using cooperative learning model on music art subjects for Husni Thamrin students which is used to improve the learning process and student competence. Therefore, the process of this research is conducted and begins with (1) preliminary study, (2) then designing instructional media, (3) validate the product, and (4) make revision and refinement based on validation data analysis from material expert, and software engineering experts conducted with individual testing, small group testing, and field trials, resulting in a learning medium that is suitable to use, in accordance with the characteristics of the field of study and students as users.

The revised and enhanced aspects of data analysis and experimentation as well as input from material experts, designers, software engineers and students as users of this interactive learning medium, aims to explore some common aspects of the process of developing a product. Learning 
media variables have an excellent average score. The learning media variables that are considered include the presentation, feasibility of content, language.

Advantages in the use of learning media by using cooperative learning model on music art subjects are as follows:

(1) he material is easy to understand because the concept presented is planned to facilitate the students and the delivery of the material systematically

(2) learning media by using cooperative learning model on the subject of music art provides an opportunity for students to learn at their own pace.

(3) learning faster and interesting so as not to generate boredom because it comes with pictures and animation and practice variety questions

(4) learning media by using cooperative learning model on music art subjects can also be used as an alternative media for individual learning

From the results of data processing research conducted, there are differences in learning results of musical arts students who learned by using learning media using cooperative learning model higher than the student learning outcomes taught by conventional learning media. Then the media that has been produced is feasible and effective to be used in learning. This is in accordance with the opinion of some relevant experts and research as follows:

(1) the use of learning media has the potential to improve learning outcomes

(2) teaching should begin from direct experience toward iconic representation and then to symbolic representation.

(3) the use of media in foreign language learning is very helpful for students, makes them feel good and makes them more active and reduces teachers' time to explain.

\section{CONCLUSION}

The conclusion of the research are as follows. (1) The validation result from the material experts, the instructional designers, and software engineering experts stated that the learning media using cooperative model on music arts subjects produced is feasible to be used in the learning.

(2) Students' learning outcomes which are taught by using instructional media by using cooperative learning model on music art subjects is higher than the result of student learning taught by using conventional learning media.

\section{References}

[1] Fathani, A. M. Seni musik, Jakarta: Ar-Ruzz, (2009), pp. 53

[2] Iswadi, D, Pengembangan MedialAlat peraga Seni musik, Depdikas. Yogyakarta. (2003), pp. 1

[3] Yohana, P. S. R., dkk. Pengembangan Media Pembelajaran Seni musik Berbantuan Komputer. Makalah. Disampaikan dalam pekan ilmiah Mahasiswa Nasional: UMM, (2016). Pp 5 and 13

[4] Sudjana, Metoda Statistika. Bandung :Tarsito, (2005), pp. 12

[5] Degeng, N.S. (1999). Paradigma Baru Pendidikan Memasuki Era Desentralisasi dan Demokrasi. Edisi 6 Tahun III 1999/2000, pp. 19
[6] Hamdani, Strategi Belajar Mengajar.Bandung: CV Pustaka Setia, (2011), pp. 42

[7] Sanjaya, Strategi Pembelajaran Berorientasi Standar Proses Pendidikan, edisi I, cetakan ke-1, kencana prenada media, (2007), pp. 196

[8] Gulo,W, Strategi Belajar Mengajar. Jakarta : PT. Grasindo, (2008), pp. $84-85$

[9] Sugiyono, Statistika Untuk Penelitian. Bandung. Penerbit: CV. Alfabeta, (2009). Pp. 407

[10] Borg, W. R., \& Gall, M. D, Educational research: an introduction (7th Ed), New York: logman, Inc, (2003)

[11] Wood, J, can software support childern's vocabulary development? (versi elektronik). Journal of language learning \& technology, (2001), pp. $166-265$ 